Original Article

\title{
Characterization of a Coliphage AS1 isolated from sewage effluent in Pakistan
}

\author{
Caracterização de um colifago AS1 isolado de efluente de esgoto no Paquistão
}

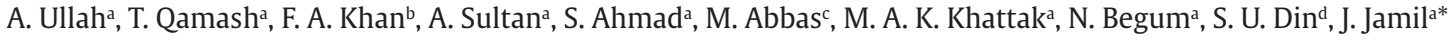 \\ and Kalsoom ${ }^{*}$ (D) \\ aUniversity of Swabi, Department of Microbiology, Swabi, KP, Pakistan \\ bUniversity of Okara, Department of Microbiology and Molecular Genetics, Okara, Pakistan \\ cAbdul Wali Khan University, Department of Pharmacy, Mardan, KP, Pakistan \\ ${ }^{d} Q u a i d$ E Azam University, Department of Microbiology, Islamabad, Pakistan
}

\begin{abstract}
The emergence of multi-drug resistant (MDR) bacterial strains, which are posing a global health threat has developed the interest of scientists to use bacteriophages instead of conventional antibiotics therapy. In light of an increased interest in the use of phage as a bacterial control agent, the study aimed to isolate and characterize lytic phages from sewage effluent. During the current study, bacteriophage AS1 was isolated from sewage effluent against E.coli S2. The lytic activity of phageAS1 was limited to E.coli S2 strain showing monovalent behavior. The calculated phage titer was $3.5 \times 10^{9} \mathrm{pfu} / \mathrm{ml}$. PhageAS1 was stable at a wide range of $\mathrm{pH}$ and temperature. The maximum stability was recorded at $37^{\circ} \mathrm{C}$ and $\mathrm{pH} 7.0$, while showing its normal lytic activity at temperature $60^{\circ} \mathrm{C}$ and from pH 5.0 to 11.0 respectively. At temperature $70^{\circ} \mathrm{C}$, phage activity was somewhat reduced whereas, further increase in temperature and decrease or increase in $\mathrm{pH}$ completely inactivated the phage. From the current study, it was concluded that waste water is a best source for finding bacteriophages against multi-drug resistant bacterial strains and can be used as bacterial control agent.
\end{abstract}

Keywords: bacteriophage, multi-drug resistant, lytic phage, phage titer, phage therapy, E.coli S2, phageAS1.

\begin{abstract}
Resumo
O surgimento de cepas bacterianas multirresistentes (MDR), que representam uma ameaça global à saúde, desenvolveu o interesse dos cientistas em usar bacteriófagos em vez da terapia convencional com antibióticos. Diante do crescente interesse no uso de fago como agente de controle bacteriano, o estudo visou isolar e caracterizar fagos líticos de efluente de esgoto. Durante o estudo atual, o bacteriófago AS1 foi isolado de efluente de esgoto contra E. coli S2. A atividade lítica de phageAS1 foi limitada à cepa E. coli S2, apresentando comportamento monovalente. O título de fago calculado foi de 3,5 x $109 \mathrm{ufp} / \mathrm{ml}$. PhageAS1 foi estável em uma ampla faixa de pH e temperatura. A estabilidade máxima foi registrada a $37^{\circ} \mathrm{C}$ e $\mathrm{pH} 7,0$, enquanto mostrou atividade lítica normal em temperatura de $60^{\circ} \mathrm{C}$ e pH 5,0 a 11,0 , respectivamente. Na temperatura de $70^{\circ} \mathrm{C}$, a atividade do fago foi um pouco reduzida, enquanto o aumento adicional da temperatura e a diminuição ou aumento do $\mathrm{pH}$ inativaram completamente $\mathrm{o}$ fago. Com base no estudo atual, concluiu-se que a água residual é a melhor fonte para encontrar bacteriófagos contra cepas bacterianas multirresistentes e pode ser usada como agente de controle bacteriano.
\end{abstract}

Palavras-chave: bacteriófago, multirresistente a drogas, fago lítico, título de fago, terapia de fago, E. coli S2, phageAS1.

\section{Introduction}

The emergence of multi-drug resistant (MDR) bacterial strains, which are posing a global health threat, has developed the interest of scientists to use bacteriophages instead of conventional antibiotics therapy. E.coli is a gram negative, rod shape and non-spore forming bacteria and a member of normal flora of human gastrointestinal tract, where it is present abundantly and helps in maintaining the normal physiology of their host (Levinson, 2014).Based on pathogenicity, E.coli is divided into two categories.
1) Enteric/Diarrheagenic E.coli. 2) Extra intestinal E.coli, which has further pathotypes. Using different mechanisms the pathotypes of Enteric E.coli can cause different types of gastrointestinal diseases and sometimes can cause disease outside the intestine (Clements et al., 2012).The pathotypes Uropathogenic of Extraintestinal E.coli is the most common cause of nosocomial UTI infection. The infection may then lead to kidney failure due to which E.coli is considered as the most common pathogen responsible for kidney failure

*e-mail: Johar.jamil@uoswabi.edu.pk; kalsoomwazir@uoswabi.edu.pk

Received: July 14, 2020 - Accepted: December 14, 2020 
(Bien et al., 2012).At the same time another calamitous issue of antibiotic resistance has emerged E.coli being the most common pathogen of humans has acquired a very high level of resistance against broad spectrum antibiotics. The resistance is not only limited to its family but has also transferred it to other species i.e. Shiga toxin-producing Escherichia coli (STEC). Furthermore, E.coli strain also make biofilm on the surface of different medical devices which is pertaining to different nosocomial infections (Surette et al., 1999; Naves et al., 2010; Choisy, 2011).

Bacteriophages are viruses having the capability to infect and multiply inside bacterial cells, and therefore their presence is directly linked to the availability of bacteria (Zhan et al., 2015).Phages are widely distributed in soil, sewage, animal wastes and their secretions (Naghavi et al., 2013). Phages are classified into two groups based on their host range. Polyvalent phages infect two or more than two bacterial species while monovalent phages infect only a single type of bacteria. Currently, antibiotic resistance has developed major medical and social problems, to resolve the issue researchers are in search of alternative therapies (WHO, 2014). Phage therapy or Lytic phages are the possible cheaper alternative for antibiotics to treat bacterial infections not responding to conventional antibiotic therapy (O'Flynn et al., 2004). The use of phages as a therapeutic agent was first given by D' Herelle. However, the concept of phage therapy canter was presented by a physician and bacteriologist named George Eliava. Later on phage therapy centre was established in Tbilisi (Capital of Georgia). Due to the keen interest in phage therapy, Western countries have successfully tested the phages on human. These include a cocktail of phages against Staphylococcus aureus, Pseudomonas aeruginosa and Escherichia coli phages which were given orally and injected showing little side effects (Kutateladze and Adamia, 2010). This study was focused on the isolation and partial characterization of novel lytic phages from sewage effluent of District Swabi.

\section{Materials and Methods}

\subsection{Bacterial strain isolation and identification}

Approximately $300 \mathrm{ml}$ sewage water was collected in a sterile bottle from different localities of district Swabi KPK Pakistan from December 2017 to April 2018. Different bacterial strains were isolated by culturing the samples on a variety of selective and differential media i.e. Mcckoncky, Eosin Methylene Blue (EMB) and Mannitol Salt Agar (MSA) using streak plate technique as well as few clinical strains were collected from local diagnostic laboratories. Each distinct colony was subcultured to get pure strains. Earlier to the plaque assays and identification tests, broth cultures of 18 to 24 hrs of each isolated and purified bacterial strain were prepared by inoculating a loop full of bacteria aseptically in a sterile flask and incubated at $150 \mathrm{rpm}$ at $37^{\circ} \mathrm{C}$ for 24 hours. After plaque assay, the only phage susceptible strain was subjected to identification using a variety of morphological (Gram staining) and biochemical tests i.e. Catalase, Indole, Citrate and Oxidase tests were performed.

\subsection{Isolation and propagation of bacteriophages}

For isolation and propagation of bacteriophages, previously established protocols with some modifications were adopted (Jamalludeen et al., 2007; Sambrook and Russell, 2001). A 10ml of 5X LB broth was inoculated with $40 \mathrm{ml}$ of collected sewage sample and enriched with $1 \mathrm{ml}$ of overnight fresh bacterial broth culture. The mixture was incubated at $37^{\circ} \mathrm{C}$ for 24 hours at $150 \mathrm{rpm}$. After incubation, $1 \mathrm{ml}$ of $1 \%$ chloroform was added to the mixture and left undisturbed for 30 minutes. The phage lysate was prepared by centrifuging the mixture at $4000 \mathrm{rpm}$ for 10 minutes followed by the filtration of supernatant through sterile $0.45 \mu \mathrm{m}$ Nylon syringe filters. The lysate was then stored at $4^{\circ} \mathrm{C}$. The phage assay was performed by two methods i.e. lawn method and Double agar or Overlay method. In the first method a lawn from broth of bacterial culture was made on LB agar plate with which the sewage sample was enriched. The plate was marked with spots and about $5 \mu l$ of phage lysate was pipetted at each spot. The plate was then left undisturbed until the lysate gets absorbed and then incubated at $37^{\circ} \mathrm{C}$ for 24 hours. Next day the plate was observed for lytic activity. While in Overlay or Double agar method, 4-5 ml of the semi-solid media LB media or Top agar (6-7g of agar in $1000 \mathrm{ml}$ of water) and $100 \mu \mathrm{l}$ of overnight bacterial broth culture was added to the sterile tube and properly mixed which is then poured over the already solidified LB agar base plate, and evenly distributed by swirling the plate gently. The plate was left undisturbed until the semi-solid media get solidified. After solidification $5 \mu$ l of phage lysate was pipetted on each spot and the plate was left undisturbed until the lysate get absorbed into the media. The plate was then incubated at $37^{\circ} \mathrm{C}$ for 24 hours and next day observed for plaques. For propagation, the phage lysate was first serially diluted. Only five dilutions $\left(10^{-1}, 10^{-3}, 10^{-5}, 10^{-7}\right.$ and $\left.10^{-10}\right)$ were selected for double agar method in order to reduce the chemical and time wastage. $100 \mu \mathrm{l}$ broth of host bacterial strain and $100 \mu l$ of phage suspension from each dilution was pipetted in fresh sterilized tubes already labeled accordingly and were incubated at $37^{\circ} \mathrm{C}$ for about 15 minutes so that the phages get attach to host bacterial cells. The bacteria-phage mixture was mixed in semi-solid LB media using vortex following the overlay procedure. After incubation, the next day a well isolated plaque was picked with a sterile pipette tip. The plaque was added to the $500 \mu \mathrm{l}$ of LB broth containing $5 \mu \mathrm{l}$ of $1 \%$ of chloroform and then vortexed so the phages get free. Again the enrichment protocol was repeated up to five times using these free phages.

\subsection{Determination of phage AS1 host ranges}

A number of bacterial strains including both sewage and clinically isolated strains of Gram-positive and Gram-negative bacteria were used for the determination of host range of AS1 phage using spot test technique (Zimmer et al., 2002). These strains include E.coliS1, E.coli S2 and E.coliC1, E.coliC2, E.coliC3, E.coliC4, Klebsiella pneumonia C1, Pseudomonas aeruginosaC1, Staphylococcus aureusS1 and Salmonella typhiS1. 


\subsection{Antibiotic susceptibility of selected host strain E. coli S2}

Using Muller Hinton Agar (MHA), Bacterial lawn was prepared on media with the help of cotton swab. A total of fifteen antibiotic discs (Table 1) were placed equally spaced on the media according to the Clinical and Laboratory Standard Institute (CLSI). The plates were incubated at $37^{\circ} \mathrm{C}$ for $18-20$ hours. After incubation, the diameter of the zones around antibiotics was measured, and the results were interpreted according to the CLSI guidelines (Wayne, 2007).

\subsection{Optimization of propagation condition of phages}

\subsubsection{Thermal stability of phage}

A previously described procedure with minor modification was used to check the thermal stability of isolated phage.100 $\mathrm{ul}$ of phage lysate was inoculated in five different micro tubes. All the tubes were subjected to different temperatures i.e. $25^{\circ} \mathrm{C}, 37^{\circ}$ (control), $50^{\circ} \mathrm{C}, 60^{\circ} \mathrm{C}$, $70^{\circ} \mathrm{C}$ and $80^{\circ} \mathrm{C}$ for 30 minutes in oven. After thermal shock at their respective temperature, the tubes were taken out from oven and were left until the phage lysate reached to room temperature. Then the stability and viability of each phage lysate were checked by spot test (Capra et al., 2006).

\subsubsection{PH Stability of Phage}

The $\mathrm{pH}$ of LB broth in seven different tubes was adjusted at 1, 3, 5, 7 (control), 9, 11 and 13 by adding Nitric acid and Sodium hydroxide. $500 \mu \mathrm{l}$ of phage lysate was added to each tube and incubated at $37^{\circ} \mathrm{C}$ for 1 hour and then neutralized. The phage lysate of all tubes were then filtered by using $0.45 \mu \mathrm{m}$ syringe filter to prevent any contamination before spot test (Capra et al., 2006).

Table 1. Antibiotics Names, Abbreviations and Potency used against Host strain E.coli S2.

\begin{tabular}{cccc}
\hline S.No & Antibiotics & Abbreviations & Potency $(\mu \mathrm{g})$ \\
\hline 01 & Cefotaxime & CTX & $30 \mu \mathrm{g}$ \\
02 & Ceftriaxone & CRO & $30 \mu \mathrm{g}$ \\
03 & Carbenicillin & CAR & $100 \mu \mathrm{g}$ \\
04 & Cephradine & CE & $30 \mu \mathrm{g}$ \\
05 & Nitrofurantoin & F & $300 \mu \mathrm{g}$ \\
06 & Imipenem & IMP & $10 \mu \mathrm{g}$ \\
07 & Cefepime & FEP & $30 \mu \mathrm{g}$ \\
08 & Chloramphenicol & C & $30 \mu \mathrm{g}$ \\
09 & Sulbactam & SCF & $105 \mu \mathrm{g}$ \\
10 & Moxifloxacin & MXF & $5 \mu \mathrm{g}$ \\
11 & Levofloxacin & LEV & $5 \mu \mathrm{g}$ \\
12 & Fosfomycin & FOS & $50 \mu \mathrm{g}$ \\
13 & Cefoperazone & CFP & $75 \mu \mathrm{g}$ \\
14 & Amikacin & AK & $30 \mu \mathrm{g}$ \\
15 & Meropenem & MEM & $10 \mu \mathrm{g}$ \\
\hline
\end{tabular}

\section{Determination of Phage Titer}

An equal volume $(100 \mu \mathrm{l})$ of serially diluted phage lysate and phage susceptible bacterial strain was added to semi-solid LB top agar, mixed and then poured over LB agar base plate. The plate was allowed to cool down and then incubated at $37^{\circ} \mathrm{C}$ (Cloki and Kropinski, 2009).The number of phages per $\mathrm{ml}$ were determined by using Formula 1 :

$$
\frac{p f u}{m l}=\frac{\text { Number of plaques }}{d x V}
$$

\section{Results}

\subsection{Bacterial strain and their respective phages characterization}

The phages susceptible strain was identified by using morphological and biochemical tests and was designated as E.colS2. The susceptible strain wasgram-negative, rod-shaped, catalase-positive, Oxidase-negative, Indole-positive, motile, methyl red positive, simmon citrate negative and produce gas from glucose. The phage was isolated using E.coliS2 as host strain and then designated as phageAS1. The phageAS1 produced plaques of diameter ranging from $1 \mathrm{~mm}$ to $1.5 \mathrm{~mm}$ with circular morphology and well defined boundaries as well as clear zones in case of spot test justifying the lytic activity of phageAS1 (Figure 1).

\subsection{Determination of phage AS1 host ranges}

Lytic activity of phageAS1 against bacterial strains is illustrated on the basis of which the host range was determined. A total of ten bacterial strains of E.coli, Klebsiella, Salmonella, Pseudomonas and Staphylococcus were screened against phageAS1, in which only E.coliS2 showed susceptibility toward the isolated phage. The phageAS1 was declared as monovalent showing high specificity towards E.colis2 strain (Table 2)

\subsection{Antibiotic susceptibility of selected host strain E. coli S2}

After 20 hours of incubation. The zones around antibiotic discs were measured. The results were then interpreted according to the Clinical and Laboratory Standard Institute (CLSI, 2007) (Table 3).

\subsection{Optimization of propagation condition of phages}

\subsubsection{Thermal stability of phage}

The heat stability of phageAS1 was screened by spot test after incubation at different temperature for 30 minutes. The phageAS1 showed optimum activity after incubation at $25^{\circ} \mathrm{C}, 37^{\circ} \mathrm{C}, 50^{\circ} \mathrm{C}$ and $60^{\circ} \mathrm{C}$ for 30 minutes. However, the lytic activity was reduced at $70^{\circ} \mathrm{C}$ and completely lost its viability at $80^{\circ} \mathrm{C}$ (Figure 2 )

\subsubsection{PH Stability of phage}

The $\mathrm{pH}$ stability of phageAS1 was checked by spot test after incubation at a wide range of $\mathrm{pH}$ for 1 hour at $37^{\circ} \mathrm{C}$. The phageAS1 showed their optimum activity at a range of pH between 5 and 11. However, further increase or decrease in $\mathrm{pH}$ resulted in the inactivation of phages (Figure 3 ). 


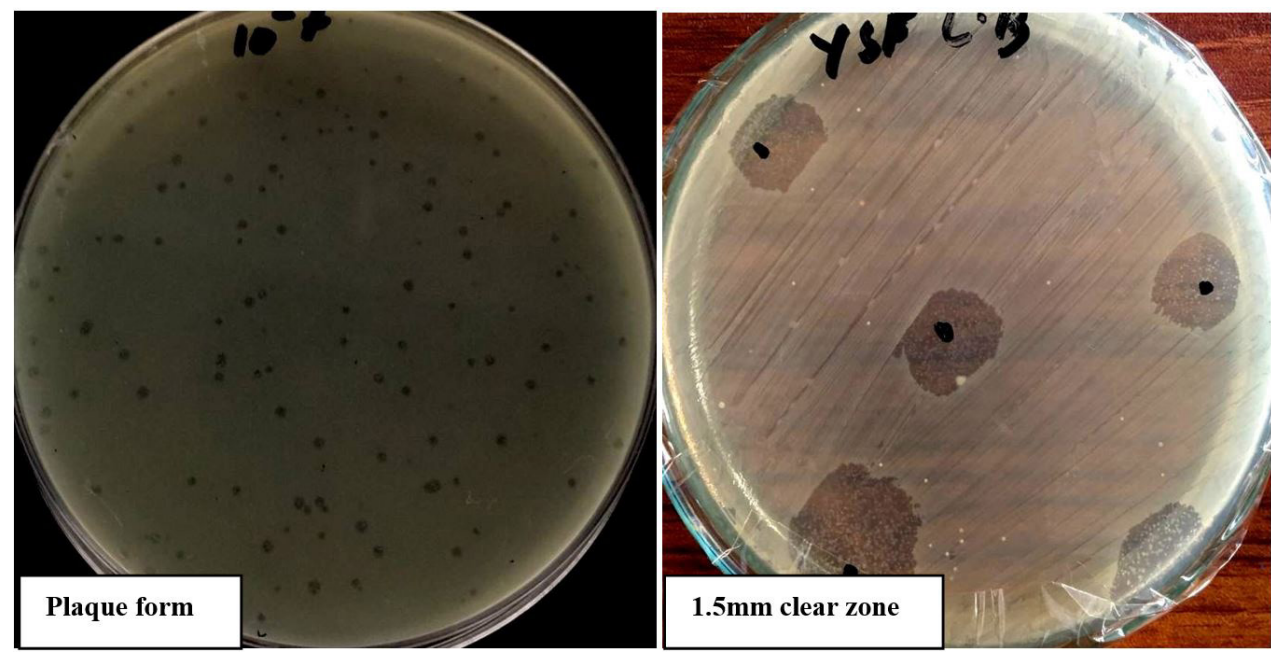

Figure 1. Plaques formation with diameter ranges $1 \mathrm{~mm}-1.5 \mathrm{~mm}$ showing lytic activity of Phage AS1 against E.coli S2 Strain.

Table 2. Antibiotic Susceptibility determination of Host strain E.coli S2.

\begin{tabular}{|c|c|c|c|c|c|}
\hline S.No. & Antibiotics & Abbreviations & Potency $(\mu \mathrm{g})$ & Zone Diameter & $\mathbf{S} / \mathbf{I} / \mathbf{R}$ \\
\hline 01 & Cefotaxime & CTX & $30 \mu g$ & $6 \mathrm{~mm}$ & $\mathrm{R}$ \\
\hline 02 & Ceftriaxone & CRO & $30 \mu g$ & $18 \mathrm{~mm}$ & S \\
\hline 03 & Carbenicillin & CAR & $100 \mu \mathrm{g}$ & $0 \mathrm{~mm}$ & $\mathrm{R}$ \\
\hline 04 & Cephradine & $\mathrm{CE}$ & $30 \mu \mathrm{g}$ & $8 \mathrm{~mm}$ & $\mathrm{R}$ \\
\hline 05 & Nitrofurantoin & $\mathrm{F}$ & $300 \mu g$ & $15 \mathrm{~mm}$ & I \\
\hline 06 & Imipenem & IMP & $10 \mu g$ & $27 \mathrm{~mm}$ & S \\
\hline 07 & Cefepime & FEP & $30 \mu \mathrm{g}$ & $11 \mathrm{~mm}$ & $\mathrm{R}$ \\
\hline 08 & Chloramphenicol & C & $30 \mu \mathrm{g}$ & $0 \mathrm{~mm}$ & $\mathrm{R}$ \\
\hline 09 & Sulbactam & SCF & $105 \mu g$ & $13 \mathrm{~mm}$ & $\mathrm{R}$ \\
\hline 10 & Moxifloxacin & MXF & $5 \mu g$ & $11 \mathrm{~mm}$ & $\mathrm{R}$ \\
\hline 11 & Levofloxacin & LEV & $5 \mu \mathrm{g}$ & $18 \mathrm{~mm}$ & S \\
\hline 12 & Fosfomycin & FOS & $50 \mu g$ & $0 \mathrm{~mm}$ & $\mathrm{R}$ \\
\hline 13 & Cefoperazone & CFP & $75 \mu \mathrm{g}$ & $15 \mathrm{~mm}$ & $\mathrm{R}$ \\
\hline 14 & Amikacin & AK & $30 \mu \mathrm{g}$ & $14 \mathrm{~mm}$ & $\mathrm{R}$ \\
\hline 15 & Meropenem & MEM & $10 \mu g$ & $11 \mathrm{~mm}$ & $\mathrm{R}$ \\
\hline
\end{tabular}

Sensitive $=\mathrm{S}$, Resistant $=\mathrm{R}$, Intermediate $=\mathrm{I}$.

Table 3. Determination of Phage AS1 Host Ranges based on lytic activity.

\begin{tabular}{ccc}
\hline S.No. & Bacterial Strain & Activity \\
\hline 1 & E.coliS1 & - \\
2 & E.colS2 & + \\
3 & E.coliC1 & - \\
4 & Klebsiella pneumonia $\mathrm{C} 1$ & - \\
5 & Pseudomonas aeruginosaC1 & - \\
6 & Staphylococcus areusS1 & - \\
7 & Salmonella typhiS1 & - \\
8 & E.coliC2 & - \\
9 & E.coliC3 & - \\
10 & E.coliC4 & - \\
\hline
\end{tabular}

$(+)=$ lytic activity and $(-)=$ No lytic activity

\subsubsection{Determination of phage titer}

For determination of phage titer $10^{-7}$ dilution plate was selected having 35 plaques thus satisfied the standard protocol by falling in between 30 to 300.Phage titer was calculated by already described formula. After interpretation of values in formula, the calculated number of phage particles per ml was $3.5 \times 10^{9} \mathrm{pfu} / \mathrm{ml}$.

\section{Discussion}

Normally, antibiotics are the main approach for the treatment of bacterial infections. But the development of antibiotic resistant bacteria has compelled the researchers to use phage therapy against bacterial infections 

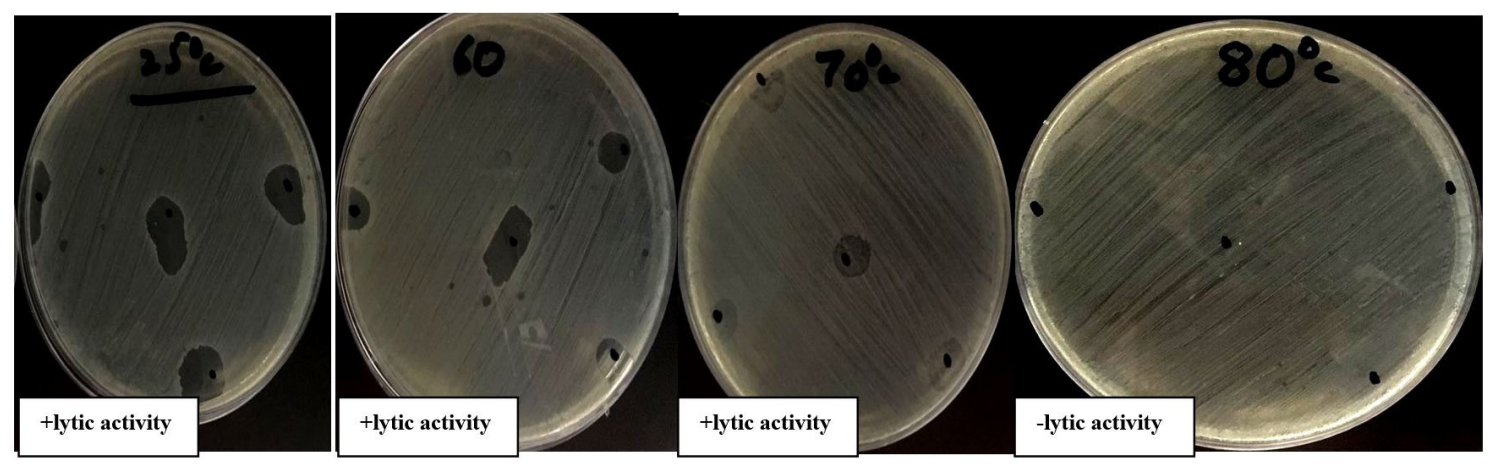

Figure 2. Themostability determination of Phage AS1 at temperature ranges $25^{\circ} \mathrm{C}-80^{\circ} \mathrm{C}$, No lytic activity observed at $80{ }^{\circ} \mathrm{C}$.
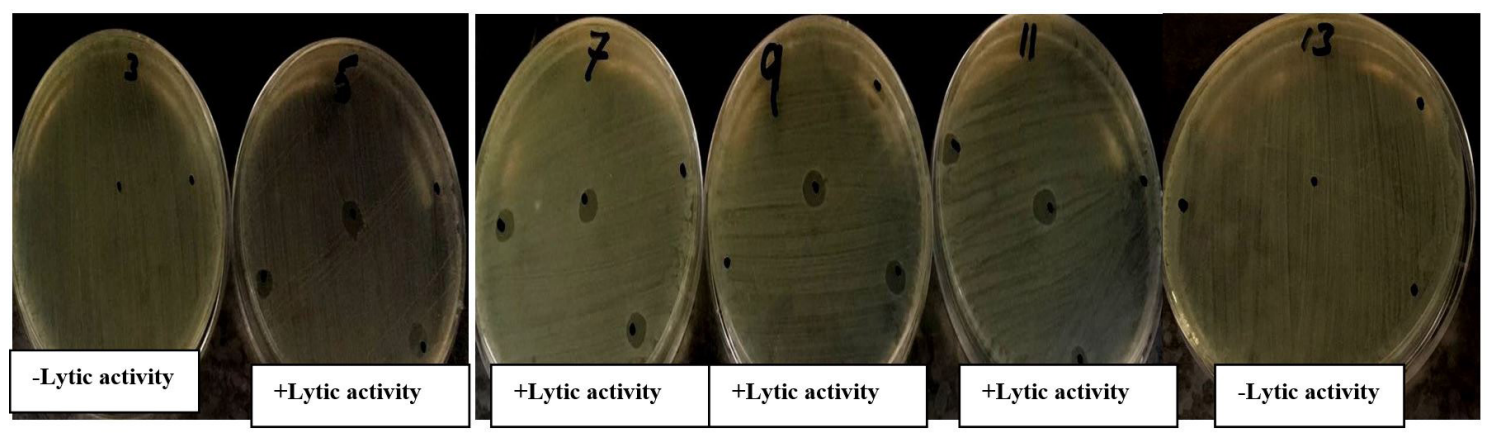

Figure 3. PH stability determination range 3-13. No lytic activity seen below PH 4 and above PH 11.

(Jamala et al., 2015). In this regard, the Eliava Institute of Bacteriophages, which is a phage therapy center in Georgia, is playing a pivotal role by testing phages for the treatment of bacterial infections (Kutter and Sulakvelidze, 2004).Escherichia coli is one of the most prevalent causes of community and hospital acquired infections across the globe (Drago et al., 2010). It has been reported that the emergence of resistance to broad-spectrum antibiotics by different strains of E.coli has become a topic of debate in scientific community fora couple of years. This issue is going worse day by day and has resulted in the availability of less or even no potent antibacterial agent against infections caused by such bacteria posing a considerable threat to public health (Bartoloni et al., 2006; Sahm et al., 2001). Howard et al. (2007). Have highlighted the multi drug resistance (MDR) bacteria as a major contribution in the failure of infection treatment, which in turn has raised the mortality rates and health cost burden.

According to the European Centre for Disease Prevention and Control (ECDC) and the Centers for Disease Control and Prevention (CDC), multi-drug resistant (MDR) strains are those, which shows resistance to at least a single antibiotic in three or more antimicrobial categories (Magiorakos et al., 2011).In the light of ECDC and CDC definitions, the isolated E.coliS2 was also declared multi drug resistant (MDR) as the strain showed resistance against Cefotaxime, Carbenicillin, Cefepime, Chloramphenicol, Fosfomycin, Cefoperazone, Amikacin, Meropenem, thus satisfied the definition of multidrug resistant strain (MDR).In such circumstances, the researchers prefer bacteriophages as a very promising agent against multi drug resistant (MDR) bacteria than that of antibiotic therapy (Sharp et al., 2006). and are testing the phages as prophylactic measures for the treatment of various infections in the Eliava institute of bacteriophages, which is a canter of phage therapy in Georgia(Kutter and Sulakvelidze, 2004).

Besides this bacteriophages are abundantly distributed in the environment, which has been estimated to be $10^{30}$ (Ashelford et al., 2000).In which the aquatic environment is the main reservoir of phages. It has been estimated that the number of phages in sewage water is $10^{8}-10^{10}$ as compared to seawater and soil (Sharp, 2001). Where it plays a key role in maintaining the optimal population of microorganisms. In the same way, these phages can also safeguard the community by removing those bacteria that are posing hazards to public health (Beheshti Maal et al., 2015). However, phages may either monovalent or polyvalent thus causing fluctuation in their host range from narrow to broad. As a result of such behaviors of phages, it is quite simple to recover phages against the foremost pathogenic bacteria i.e. E. coli, P. aeruginosa, Campylobacter, Salmonella and S. aureus (Hyman and Abedon, 2010). Several investigators have isolated and used the phages for treatment and prophylaxis of E.coli infections in animals i.e. lambs, calves, and piglets.The importance of phage therapy can also be determined from the fact that the wounds that have developed resistance to antibiotics resulting in various infectious diseases are now treated with phages, which includes the treatment of lung infections, meningitis, osteomyelitis and other wound infections caused by a variety of microbes including E. coli, P. aeruginosa, Shigella, Staphylococcus etc (Monk et al., 2010). 
Due to the increase of bacterial resistance to antibiotics and the ability of phage therapy to eliminate these bacteria, it is essential to isolate, characterize and screen novel phages against multidrug resistant bacteria (Sillankorva et al., 2008). Therefore, In this study a bacteriophage was isolated from sewage water sample designated as AS1 against E.coli strain isolated from sewage and then designated as S2. The sewage water sample was selected for isolation of phage against E.coli being the favorite niche for the host as well as the sewage contains a wide variety of microbes due to fecal wastes in sewage water (Piracha et al., 2014). The isolated phage AS1 was highly lytic and produced clear plaques of diameter ranges from $1 \mathrm{~mm}$ to $1.5 \mathrm{~mm}$ (Shende et al., 2017).

The study aimed to isolate phages against bacterial strain. Numerous phages can only recognize and bind to their specific receptor present on the surface of their host cell and cannot recognize other receptors (Piracha et al., 2014). E.coli 22 strain was the only strain that was sensitive to the isolated phageAS1, thus justified the high specificity toward the receptors of S2 strain. This characteristic made the isolated phage monovalent being capable of infecting a single strain (Chan et al., 2013). Previous studies revealed that increase in temperature decreases the inactivation rate of phages (Feng et al., 2003). Many phages that have been studied can survive at $50^{\circ} \mathrm{C}$ temperature and inactivated when heated at $60^{\circ} \mathrm{C}$ for 30 minutes (Ackermann, 2007). Similarly, isolated phage AS1 was highly stable up to $60^{\circ} \mathrm{C}$. A further increase in temperature affects its activity and stability. At $70^{\circ} \mathrm{C}$, the phage was fairly stable, whereas at $80^{\circ} \mathrm{C}$ the phage was completely inactivated. The results of heat stability of isolated phageAS1 was similar to the results of a study conducted in 2012 (Haq et al., 2012). The previous studies have stated that the inactivation rate of phages increase when then $\mathrm{pH}$ is either increase above 8.0 or decrease below 6 (Feng et al., 2003). Most of the phages remain viable in a $\mathrm{pH}$ ranging from 5.0-9.0. The isolated phageAS1 also showed an excellent stability at wide range of $\mathrm{pH}$. The phage was relatively stable and showed normal lytic activity from 5.0-11.0. However, at pH 1.0 and 3.0 the phage was inactivated as the acidity causes the protein denaturation of phages. In the same way at $\mathrm{pH} 13.0$ and 14.0 the phage completely lost its stability (Hazem, 2002). The pH stability of phageAS1 showed similarity toward an earlier observation (Jamalludeen et al., 2007).

\section{Conclusion}

To conclude, the sewage water is an excellent source of therapeutic bacteriophages against multi-drug resistant (MDR) bacterial strains. As the currently isolated E.coli S2 was a multi-drug resistant (MDR) strain. The isolated phageAS1 was recognized as highly specific and monovalent lytic coli-phage infecting only E.coli S2 strain out of the ten different strains. The isolated phage was stable at wide range of $\mathrm{pH}$ and temperature. These characteristics make the phage to adopt diverse environmental and industrial conditions. Thus the phage therapy can be the best and cheaper alternative therapy against infections that have developed resistance to antibiotics.

\section{Acknowledgements}

Department of Microbiology, University of Swabi, KP, Pakistan. Diagnostic Center and Laboratory Services Swabi, for providing clinical strains.

\section{References}

ACKERMANN, H.W., 2007. Phages examined in the electron microscope. Archives of Virology, vol. 152, no. 2, pp. 227-243. http://dx.doi.org/10.1007/s00705-006-0849-1. PMid:17051420.

ASHELFORD, K.E., NORRIS, S.J., FRY, J.C., BAILEY, M.J. and DAY, M.J., 2000. Seasonal population dynamics and interactions of competing bacteriophages and their host in the rhizosphere. Applied and Environmental Microbiology, vol. 66, no. 10, pp. 41934199. http://dx.doi.org/10.1128/AEM.66.10.4193-4199.2000. PMid:11010859.

BIEN, J., SOKOLOVA, O., and BOZKO, P., 2012. Role of uropathogenic Escherichia coli virulence factors in development of urinary tract infection and kidney damage. International journal of nephrology, vol. 2012, pp. 681473.

BARTOLONI, A., PALLECCHI, L., BENEDETTI, M., FERNANDEZ, C., VALLEJOS, Y., GUZMAN, E., VILLAGRAN, A.L., MANTELLA, A., LUCCHETTI, C., BARTALESI, F., STROHMEYER, M., BECHINI, A., GAMBOA, H., RODRÍGUEZ, H., FALKENBERG, T., KRONVALL, G., GOTUZZO, E., PARADISI, F. and ROSSOLINI, G.M., 2006. Multidrug-resistant commensal Escherichia coli inchildren, Peru and Bolivia. Emerging Infectious Diseases, vol. 12, no. 6, pp. 907-913. http://dx.doi.org/10.3201/eid1206.051258.

BEHESHTI MAAL, K., SOLEIMANI DELFAN, A. and SALMANIZADEH, S., 2015. Isolation and Identification of Two Novel Escherichia coli bacteriophages and their application in wastewater treatment and coliform'sPhage Therapy. Jundishapur Journal of Microbiology, vol. 8, no. 3, pp. e14945. http://dx.doi.org/10.5812/jjm.14945. PMid:25834715.

CAPRA, M.L., QUIBERONI, A. and REINHEIMER, J., 2006. Phages of Lactobacillus casei/paracasei: response to environmental factors and interaction with collection and commercial strains. Journal of Applied Microbiology, vol. 100, no. 2, pp. 334-342. http:// dx.doi.org/10.1111/j.1365-2672.2005.02767.x. PMid:16430510.

CHAN, B.K., ABEDON, S.T. and LOC-CARRILLO, C., 2013. Phage cocktails and the future of phage therapy. Future Microbiology, vol. 8, no. 6, pp. 769-783. http://dx.doi.org/10.2217/fmb.13.47. PMid:23701332.

CHOISY, C., 2011. Biofilms et Santé publique : à propos de l'examen de 402 cathéters veineux centraux, mis en place dans un service de chirurgie générale et digestive. Bulletin de l'Académie Nationale de Médecine, vol. 195, no. 4-5, pp. 1105-1120. http:// dx.doi.org/10.1016/S0001-4079(19)32022-9. PMid:22375373.

CLEMENTS, A., YOUNG, J. C., CONSTANTINOU, N., and FRANKEL, G., 2012. Infection strategies of enteric pathogenic Escherichia coli. Gut microbes, vol. 3, no. 2, pp. 71-87.

CLOKI, M.R.J. and KROPINSKI, A.M., 2009. Bacteriophages, methods and protocols. isolation, characterization and interactions. New York: Humana Press.

CLINICAL AND LABORATORY STANDARD INSTITUTE - CLSI, 2007. Performance Standards for Antimicrobial Susceptibility Testing. Wayne, PA, USA: Clinical and Laboratory Standards Institute; CLSI M100-S17.

DRAGO, L., NICOLA, L., MATTINA, R. and DE VECCHI, E..2010. In vitro selection of resistance in Escherichia coli and Klebsiella spp. at in vivo fluoroquinolone concentrations. BMC Microbiology, vol. 
10, no. 1, pp. 119. http://dx.doi.org/10.1186/1471-2180-10-119. PMid:20409341.

FENG, Y.Y., ONG, S.L., HU, J.Y., TAN, X.L. and NG, W.J., 2003. Effect of $\mathrm{pH}$ and temperature on the survival of coliphages $\mathrm{MS}_{2}$ and $\mathrm{Q} \beta$. Journal of Industrial Microbiology E Biotechnology, vol. 30, no. 9, pp. 549-552. http://dx.doi.org/10.1007/s10295-0030080-y. PMid:12942371.

HAQ, I.U., CHAUDHRY, W.N., ANDLEEB, S., and QADRI, I., 2012. Isolation and partial characterization of a virulent bacteriophage IHQ1 specific for aeromonas punctata from stream water. Microbial Ecology, vol. 63, no. 4, pp. 954-963.

HAZEM, A., 2002. Effects of temperatures, pH-values, ultra-violet light, ethanol and chloroform on the growth of isolated thermophilic Bacillus phages. The New Microbiologica, vol. 25, no. 4, pp. 469-476. PMid:12437227.

HOWARD, R. L., AVERY, A. J., SLAVENBURG, S., ROYAL, S., PIPE, G., LUCASSEN, P., and PIRMOHAMED, M., 2007. Which drugs cause preventable admissions to hospital? A systematic review. British journal of clinical pharmacology, vol. 63, no. 2, pp. 136-147.

HYMAN, P. and ABEDON, S.T., 2010. Bacteriophage host range and bacterial resistance. Advances in Applied Microbiology, vol. 70, pp. 217-248. http://dx.doi.org/10.1016/S0065-2164(10)700071. PMid:20359459.

JAMALA, M., HUSSAINA, T., DASB, C. and ANDLEEBA, S., 2015. Inhibition of clinical multi-drug resistant Klebsiella pneumoniae biofilm by Siphoviridae bacteriophage. Z. Sci Lett., vol. 3, no. 2, pp. 122-126.

JAMALLUDEEN, N., JOHNSON, R.P., FRIENDSHIP, R., KROPINSKI, A.M., LINGOHR, E.J. and GYLES, C.L., 2007. 'Isolation and characterization of nine bacteriophages that lyse 0149 enterotoxigenic Escherichia coli. Veterinary Microbiology, vol. 124, no. 1-2, pp. 47-57. http://dx.doi.org/10.1016/j. vetmic.2007.03.028. PMid:17560053.

KUTATELADZE, M. and ADAMIA, R., 2010. Bacteriophages As potential new therapeutics to replace or supplement antibiotics. Trends in Biotechnology, vol. 28, no. 12, pp. 591-595. http://dx.doi. org/10.1016/j.tibtech.2010.08.001. PMid:20810181.

KUTTER, E. and SULAKVELIDZE, A., 2004. Bacteriophages: biology and applications. USA. CRC Press. http://dx.doi. org/10.1201/9780203491751.

LEVINSON, W., 2014. Review of medical microbiology and immunology. $3^{\text {rd }}$ ed. New York: McGraw-Hill.

MAGIORAKOS, A.P., SRINIVASAN, A., CAREY, R.B., CARMELI, Y., FALAGAS, M.E., GISKE, C.G., HARBARTH, S., HINDLER, J.F., KAHLMETER, G., OLSSON-LILJEQUIST, B., PATERSON, D.L., RICE, L.B., STELLING, J., STRUELENS, M.J., VATOPOULOS, A., WEBER, J.T. and MONNET, D.L., 2011. Multidrug-resistant, extensively drug-resistant and pandrug-resistant bacteria: an international expert proposal for interim standard definitions for acquired resistance. Clinical microbiology and infection : the official publication of the European Society of Clinical Microbiology and Infectious Diseases, vol. 18, no. 3, pp. 268-281. http://dx.doi. org/10.1111/j.1469-0691.2011.03570.x. PMid:21793988.

MONK, A., REES, C., BARROW, P., HAGENS, S. and HARPER, D., 2010. Bacteriophage applications: where are we now? Letters in Applied Microbiology, vol. 51, no. 4, pp. 363-369. http://dx.doi. org/10.1111/j.1472-765X.2010.02916.x. PMid:20796209.

NAGHAVI, N.S., GOLGOLJAM, M. and AKBARI, M., 2013. Effect of three sewage isolated bacteriophages on the multi drug resistant pathogenic bacteria. The Journal of Biological Sciences, vol. 13, no. 5, pp. 422-426. http://dx.doi.org/10.3923/jbs.2013.422.426.
NAVES, P., DEL PRADO, G., HUELVES, L., RODRIGUEZ-CERRATO, V., RUIZ, V., and PONTE, M.C., 2010. Effects of human serum albumin, ibuprofen and Nacetyl-L-cysteine against biofilm formation by pathogenic Escherichia coli strains. The Journal of Hospital Infection, vol. 76, no. 2, pp. 165-170. PubMed: 20615578.

O'FLYNN, G., ROSS, R.P., FITZGERALD, G.F. and COFFEY, A., 2004. Evaluation of a cocktail of three bacteriophages for biocontrol of Escherichia coli 0157:H7. Applied and Environmental Microbiology, vol. 70, no. 6, pp. 3417-3424. http://dx.doi.org/10.1128/ AEM.70.6.3417-3424.2004. PMid:15184139.

PIRACHA, Z., SAEED, U., KHURSHID, A., and CHAUDHARY, W. N., 2014. Isolation and partial characterization of virulent phage specific against Pseudomonas aeruginosa. Global Journal of Medical Research: C Microbiology and Pathology, vol. 14, no. 1, pp. 1-9.

SAHM, D.F., THORNSBERRY, C., MAYFIELD, D.C., JONES, M.E. and KARLOWSKY, J.A., 2001. Multidrug-resistant urinary tract isolates of Escherichia coli: prevalence and patient demographics in the United States. Antimicrobial Agents and Chemotherapy, vol. 45, no. 5, pp. 1402-1406. http://dx.doi.org/10.1128/AAC.45.5.14021406.2001. PMid:11302802.

SAMBROOK, J. and RUSSELL, D.W., 2001. Molecular cloning- $A$ laboratory manual. New York. Cold Spring Harbor Laboratory Press.

SHARP, R., 2001. Bacteriophages: biology and history. Journal of Chemical Technology and Biotechnology (Oxford, Oxfordshire), vol. 76, no. 7, pp. 667-672. http://dx.doi.org/10.1002/jctb.434.

SHARP, R., HUGHES, G., HART, A. and WALKER, J.T. Bacteriophage for the treatment of bacterial biofilms. U.S.A. Patent 20,060,140,911. 29-6-2006.

SHENDE, R.K., HIRPURKAR, S.D., SANNAT, C., RAWAT, N. and PANDEY, V., 2017. Isolation and characterization of bacteriophages with lytic activity against common bacterial pathogens. Veterinary World, vol. 10, no. 8, pp. 973-978. http://dx.doi.org/10.14202/ vetworld.2017.973-978. PMid:28919692.

SILLANKORVA, S., NEUBAUER, P. and AZEREDO, J., 2008. Pseudomonas fluorescens biofilms subjected to phage philBB-PF7A. BMC Biotechnology, vol. 8, pp. 79. http://dx.doi. org/10.1186/1472-6750-8-79. PMid:18954451.

SURETTE, M.G., MILLER, M.B. and BASSLER, B.L., 1999. Quorum sensing in Escherichia coli, Salmonella typhimurium, and Vibrio harveyi: a new family of genes responsible for auto inducer production. Proceedings of the National Academy of Sciences of the United States of America, vol. 96, no. 4, pp. 1639-1644. http:// dx.doi.org/10.1073/pnas.96.4.1639. PMid:9990077.

WAYNE, P., 2007. Implementation Guide of POCT for health care providers. Philadelphia: CLSI, pp. 1-37.

WORLD HEALTH ORGANIZATION - WHO, 2014 [viewed 9 May 2018]. Antimicrobial resistance: global report on surveillance [online]. Geneva: WHO. Available from: http://www.who. int/drugresistance/documents/AMR_report_Web_slide_set. pdf?ua $=1$

ZHAN, Y., BUCHAN, A. and CHEN, F., 2015. Novel N4 bacteriophages prevail in the cold biosphere. Applied and Environmental Microbiology, vol. 81, no. 15, pp. 5196-5202. http://dx.doi. org/10.1128/AEM.00832-15. PMid:26025897.

ZIMMER, M., SCHERER, S. and LOESSNER, M.J., 2002. Genomic analysis of Clostridium perfringens bacteriophage $\varphi 3626$, which integrates into guaA and possibly affect sporulation. Journal of Bacteriology, vol. 184, no. 16, pp. 4359-4368. http://dx.doi. org/10.1128/JB.184.16.4359-4368.2002. PMid:12142405. 